\title{
Jurnal Informatika Ekonomi Bisnis
}

\author{
http://www.infeb.org
}

\section{Sistem Pendukung Keputusan terhadap Jenis dan Penerima dalam Penentuan Bantuan Desa Menggunakan Metode Simple Additive Weighting}

\author{
$\mathbb{R}_{\text {andi }}$ Afrii $\mathbb{N a n d e s}^{1 \times}$ \\ ${ }^{1}$ Universitas Putra Indonesia Y YPTK Padang \\ randi.afrinandes@yahoo.com
}

\begin{abstract}
Sidoluhur Village is a village located in Padang Jaya District, North Bengkulu which has a large population. The his village has 3 hamlets in one village. The problem in Sidoluhur Village is that it is difficult to determine the recipient of village assistance, because the number of aid proposals that are proposing is more than the number of people who receive assistance. There are so many proposals that have been submitted, this is of course very troublesome for village officials who choose to receive assistance. As problems develop, a decision support system is needed that will provide results on the computer to determine who should get help. A decision support system is a system for finding decision support, decisions are taken using a system designed based on usage needs, in helping to make decisions, decisions are designed based on predetermined criteria and alternatives and have a system that is structured and programmed in the form of weighting that will be accumulated and normalized and produce ranking. This study uses the Simple Additive weighting method, commonly referred to as a method that uses a weighted additive form. The form of the method is to calculate the total weight value of the work steps on the existing alternatives of all attributes. To explain about the completion of the method uses village aid recipient data. A lot of data that will be used as alternatives in this study are 9 candidates for village aid recipients. As a result, the recipients of aid should not be less than 0.5000 , with the result that 7 recipients of assistance and 2 people who are not eligible to receive assistance.
\end{abstract}

Keywords: Decision Support Systems, Village, Intensive, Simple Additive Weighting (SAW), Bansos.

\begin{abstract}
Abstrak
Desa Sidoluhur adalah Desa yang terletak di Kecamatan Padang Jaya, Bengkulu Utara yang memiliki jumlah penduduk cukup banyak. Desa ini memiliki 3 dusun yang terdapat dalam satu Desa. Adapun permasalahan yang ada di Desa Sidoluhur yaitu dalam penentuan penerima bantuan desa yang sulit tentukan, karena jumlah proposal bantuan yang mengusul lebih banyak dari jumlah orang yang menerima bantuan. Sekian banyak proposal yang masuk, hal ini tentu sangat merepotkan aparat desa yang memilih menerima bantuan. Seiring berkembangnya masalah, diperlukan sistem pendukung keputusan yang akan memberikan hasil di komputer untuk menentukan siapa yang harus mendapatkan bantuan. Sistem penunjang keputusan adalah sebuah sistem untuk mencari penunjang keputusan ,keputusan diambil menggunakan sistem yang dirancang berdasarkan kebutuhan pemakaian, dalam membantu mengambil suatu keputusan, keputusan dirancang berdasarkan kriteria dan alternatife yang sudah ditentukan sebelumnya dan memiliki sistem yang sudah terstruktur dan terprogram dalam bentuk pembobotan yang akan diakumulasi dan dinormalisasikan dan menghasilkan perangkingan. Penelitian ini menggunakan metode Simple Additive weighting (SAW)biasa disebut sebagai metode yang menggunakan bentuk penjumlah terbobot. Bentuk dari metode yaitu menghitung jumlah nilai bobot dari langkah-langkah kerja pada alternatif yang ada dari semua atribut. Untuk menjelaskan tentang penyelesaian metode menggunakan data penerima bantuan desa. Banyak data yang akan dijadikan alternatif pada penelitian ini sebanyak 9 orang kandidat penerima bantuan desa. Dengan hasil penerima bantuan tidak boleh kurang dari 0.5000 dengan hasil 7 orang penerima bantuan dan 2 orang yang tidak layak menerima bantuan.
\end{abstract}

Kata Irumei: Sistem Pendukung Keputusan,Bantuan, Desa, Simple Additive Weighting (SAW), Bansos.

(C) 2021 INFEB

\section{Pendahuluan}

Dalam kemajuan dari sebuah teknologi khususnya komputer sekarang banyak menghasilkan perubahan pada aspek kehidupan manusia [1]. Desa Sidoluhur adalah Desa yang terletak di Kecamatan Padang Jaya, Bengkulu Utara yang memiliki jumlah penduduk cukup banyak, yang mana desa ini memiliki 3 dusun yang terdapat dalam satu Desa. Adapun permasalahan yang ada di Desa Sidoluhur yaitu dalam penentuan penerima bantuan desa yang sulit tentukan, karena jumlah proposal bantuan yang mengusul lebih banyak dari jumlah orang yang menerima bantuan. Sekian banyak proposal yang masuk, hal ini tentu sangat merepotkan aparat desa yang memilih menerima bantuan.

Program Kartu Indonesia Pintar (KIP) ialah salah satu bentuk dari program bantuan pemerintah, dalam pemberian bantuan tunai. Untuk menerima 
KIP,keluarga yang menerima bantuan KIP ini berasal dari keluarga kurang mampu/ miskin, dan anak yang memenuhi kriteria yang sudah dipilih sebelumnya [2]. Bantuan Langsung Tunai (BLT) adalah bantuan yang diberikan dari pemerintah kepada keluarga kurang mampu fakir miskin, agar mereka bisa meningkatkan taraf kesejahteraan sosialnya agar bisa mengurangi beban ekonomi yang semakin menekan kehidupan mereka, sebagai akibat naiknya harga bahan pokok sehari-hari dan juga harga BBM yang bisa menganggu perekonomian [3]. Sistem ialah suatu bentuk jaringan kerja dari prosedur-prosedur yang saling berhubungan, dan berkumpul bersama-sama untuk melakukan suatu kegiatan atau untuk menyelesaikan suatu sasaran tertentu. Terdapat dua kelompok pendekatan dalam mendefinisikan sistem, yaitu pendekatan yang menekankan pada prosedurnya dan pendekatan yang menekankan pada komponen atau elemennya. Adapun pendekatan sistem yang kedua yaitu pendekatan yang menekankan pada komponen atau elemennya mendefinisikan dari elemen-elemen sistem [4]. Sistem penunjang keputusan adalah sebuah sistem untuk mencari penunjang keputusan-keputusan diambil menggunakan sistem yang dirancang berdasarkan kebutuhan pemakaian dalam membantu mengambil suatu keputusan keputusan dirancang berdasarkan kriteria dan alternatif yang sudah ditentukan sebelumnya dan memiliki sistem yang sudah terstruktur dan terprogram dalam bentuk pembobotan yang akan diakumulasi dan dinormalisasikan dan menghasilkan perangkingan [5]. Tahap-tahap proses dalam sistem pendukung keputusan sebagai berikut [6].

a. Penelusuran (Inteligence), adalah proses dari penelusuran dan pendeteksian elemen-elemen penyebab masalah yang terjadi.

b. Desain (Desain), merupakan rancangan dari beberapa metode yang bisa meneyelesaikan masalah.

c. Pemilihan (choice) yaitu memilih salah satu aternatif desain dalam menyelesaikan masalah tersebut.

d. Penerapan (Implementation) yaitu, metode yang menerapkan yang dipilih dalam suatu sistem yang menggunakan alat komputer sebagai alat baru.

Konsep dari sistem pendukung keputusan (SPK), awal kali dikenalkan oleh Michael S. Scott Morton pada mula tahun 1970-an, kemudian diketahui dengan nama Management. Decision System (DSS), ini didefinisikan sebagai sebuah sistem yang interaktif yang menyediakan bentuk dalam model dari sistem dan memanipulasi dari bentuk data dan juga informasi. Sistem ini dapat dimanfaatkan sebagai alat buat menolong dalam mengambil suatu keputusan pada situasi yang tersusun, tidak banyak orang mengetahui hasil dengan benar keputusan itu harusnya diambil [7]. Pengambilan Keputusan ialah sesuatu pendekatan yang sistematis terhadap sesuatu permasalahan yang dialami. Dari uraian pengambilan keputusan diatas, bisa disimpulkan kalau pengambilan keputusan ialah sesuatu proses pemilihan alternatif terbaik dari sebagian alternative [8]. Sistem berbasis pengetahuan ataupun menajemen pengetahuan yang dipakai buat menunjang pengambilan keputusan dalam suatu organisasi ataupun industri. Bisa pula dikatakan selaku sistem pc yang mencerna informasi jadi data buat mengambil keputusan dari permasalahan semi terstruktur yang khusus [9]. Sistem pendukung keputusan melaksanakan proses pengolahan informasi dengan sistem komputerisasi dalam pengambilan keputusan. Hasil keputusan tersebut diperoleh dari pengolahan informasi, data serta rancangan model. Dari banyak tata cara di dalam SPK salah satunya tata cara Sederhana Simple Additive Weighting [10]. Adapun tujuan dari sebuah sistem pendukung keputusan (SPK) ini yaitu antara lain untuk mendukung menentukan keputusan pada proses pengambilan sebuah keputusan menggunakan alternatif-alternatif yang diperoleh dari hasil pengolahan data, yang memiliki informasi dan rancangan model. Karakteristik dari SPK ini adalah mendukung seluruh kegiatan organisasi mendukung beberapa keputusan yang saling berinteraksi terdapat dua komponen yaitu data dan model yang bersifat konstan [11]. Penelitian mengenai sistem pendukung keputusan diantaranya yang melakukan penelitian mengenai penerimaan jurnalis dengan data berupa 5 alternatif dan 5 kriteria yang menghasilkan keputusan berupa alternatif ke 5 yang terpilih menjadi jurnalis, kesimpulan yang didapat bahwa sistem pendukung keputusan cukup membantu memudahkan untuk menentukan jurnalis baru dan memiliki proses-proses menyelesainnya cukup sederhana [12]. Penelitian selanjutnya mengenai menentukan anggota penari terbaik. Dengan data 5 orang siswa dan 8 kriteria, dari hasil nilai yang didapat maka V1, V2, V3, V4, V5 didefenisikan sebagai anggota penari yang berkualitas dan memiliki nilai tertinggi dengan skor 100 yang didapat dari V2 [13]. Penelitian selanjutnya mengenai menentukan siswa terbaik. Dengan data 5 orang siswa dan kriteria 3 didapatkan alternatif yang memiliki nilai preferensi tertinggi 0,979 dan seterusnya menentukan siswa terbaik [14]. Penelitian selanjutnya melakukan penelitian mengenai pemilihan dalam menentukan lokasi cabang yang baru pada toko pakan ikan dengan data berupa 5 alternatif dan 6 kriteria yang menghasilkan keputusan berupa alternatif ke 5 yang terpilih menjadi lokasi untuk cabang toko baru, kesimpulan yang didapat bahwa dengan metode simple additive weighting (SAW) bisa dijadikan sebagai suatu system pendukung keputusan dalam suatu permasalahan yang ada, sehingga bisa memberikan keuntungan dalam menentukan keputusan yang akan diambil [15]. Penelitian selanjutnya menjelaskan penerbitan penyetujuan kartu kredit pada bank bri dengan data 5 alternatif dan 6 kriteria yang menghasilkan keputusan berupa alternatif ke 3 yang yang disetujui dan 2 yang tidak setujui [16]. Penelitian selanjutnya mengenai penanganan pasien rumah sakit yang memilih data pasien 2 orang dan kriteria 5, didapatkan alternatif yang memiliki 1 pasien yang dirawat untuk rujukan operasi dan 1 pasien tidak dirawat [17]. Metode 
Simple Additive Weighting (SAW) biasa disebut sebagai metode yang menggunakan bentuk penjumlah tertimbang bentuk dari metode yaitu menghitung jumlah nilai bobot dari langkah-langkah kerja pada alternatif yang ada dari semua atribut [18]. Metode SAW lebih efisien karena hanya membutuhkan waktu perhitungan yang lebih singkat. Metode gelombang akustik permukaan perlu dinormalisasi pada matriks keputusan (X), dan skalanya dapat dibandingkan dengan semua nilai alternatif yang ada. Metode SAW mengenal adanya 2 (dua) atribut yaitu kriteria keuntungan (benefit) dan kriteria biaya (cost). Perbedaan mendasar dari kedua kriteria ini adalah dalam pemilihan kriteria ketika mengambil keputusan.

\section{Metodologi Penelitian}

Metodologi membahas mengenai konsep teoritik yang dalam penerapannya digunakan di berbagai metode, dimana terdapat kelebihan dan kelemahan pada setiap metode. Salah satu unsur yang penting dalam metode penelitian adalah bagaimana metode yang digunakan sesuai dalam penelitian dengan tujuan pencarian masalah untuk dipecahkan dalam penelitian yang sedang di teliti. Sehingga dapat dipertanggungjawabkan kebenaran hasilnya yang diperoleh secara ilmiah.

Metode penelitian merupakan langkah-langkah ataubentuk proses yang akan dilakukan dalam penelitian, agar penelitian ini bisa terlaksana dengan baik dan terstruktur. Adapun langkah yang harus dilakukan mulai dari mempelajari proses penelitian, sampai dengan adanya suatu sistem yang dapat memberikan penyelesaian masalah yang sedang diteliti.

Kerangka kerja adalah langkah-langkah dalam penelitian yang akan dilakukan untuk menyelesaikan suatu masalah yang akan dibahas. Tujuan membuat kerangka kerja adalah untuk membuat tahapantahapan yang akan dilakukan dalam penelitian. Setiap tahapan dilakukan sesuai dengan perencanaan. Semua tahapan pada kerangka penelitian berpengaruh pada tahapan berikutnya. Adapun kerangka kerja penelitian yang dilakukan oleh penulis dan disajikan pada Gambar 1 .

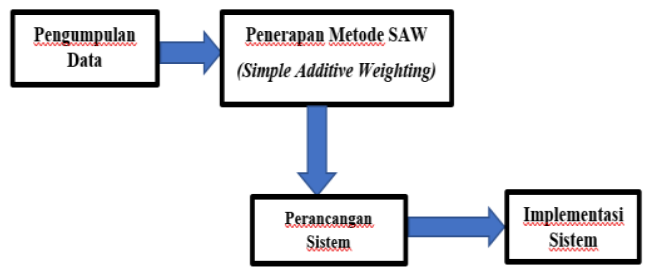

Gambar 1. Kerangka Kerja Penelitian

\subsection{Pengumpulan Data}

Pada bagian ini penulis menjelaskan bagaimana data diperoleh, berdasarkan metode pengumpulan data pada bab sebelumnya. Penulis melakukan wawancara langsung dengan Kepala Desa Padang Jaya Bengkulu
Utara. Sehingga Penulis mendapatkan informasi beserta data yang akan menjadi penerima bantuan desa pada tingkat Kecamatan Padang Jaya, Bengkulu Utara serta mendapatkan alternatif dari setiap penerima bantuan desa.

\subsection{Banyak Data}

Untuk menjelaskan tentang penyelesaian metode penulis menggunakan data penerima bantuan desa. Banyak data yang akan dijadikan alternatif pada penelitian ini sebanyak 9 orang kandidat penerima bantuan desa.

\subsection{Jenis Data}

Jenis data yang dimaksud disini adalah jenis data yang didapatkan pada saat melakukan penelitian, penulis mendapatkan data dari desa sidoluhur berupa data Excel dan juga penulis mendapatkan data dengan melakukan wawancara kepada warga desa sidoluhur, padang jaya.

\section{Hasil dan Pembahasan}

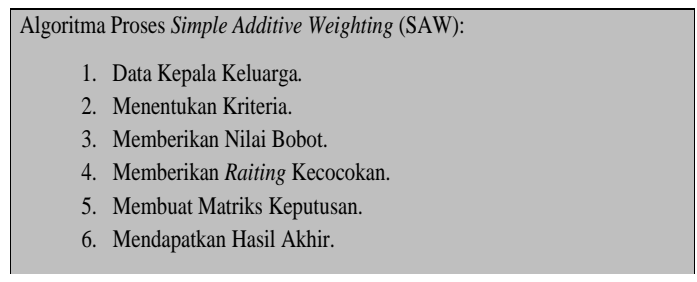

Gambar 2. Proses Metode Simple Additive Weighting

\subsection{Data}

Data yang digunakan pada penelitian ini adalah data yang diambil dan diolah dari data indeks penduduk Desa Sidoluhur Padang Jaya. Data yang digunakan untuk pengolahan sebanyak 9 data. Data diambil dengan cara meminta kepada Desa sidoluhur Padang Jaya, Bengkulu Utara melalui bagian pendataan masyarakat desa sidoluhur untuk memberikan izin atas data penerima bantuan desa yang akan diolah, tentunya terlebih dahulu dengan meminta izin penelitian disertai surat izin penelitian dan pengambilan data dari kampus. Data alternatif yang di sajikan pada Tabel 1 .

Tabel 1. Alternatif Data Kepala Keluarga

\begin{tabular}{ll}
\hline Nama & Kode \\
\hline Sudarno & K1 \\
Widiadi & K2 \\
Tukijo & K3 \\
Sarkam & K4 \\
Yardani & K5 \\
Susilawati & K6 \\
Suderman & K7 \\
Suwarjo & K8 \\
Nurman Sitikno & K9 \\
\hline
\end{tabular}

\subsection{Menentukan Kriteria}

Proses pada pembuatan sistem pendukung keputusan memastikan Penerima Bantuan Desa, diperlukan pembobotan dari tiap kriteria yang sudah ditetapkan. Ada 4 (Empat) kriteria yang hendak digunakan dalam memastikan Penerima Pertolongan dari Desa. Ada 
pula kriteria serta pembobotan yang disajikan pada Tabel 2, 3, 4, 5, 6 .

Tabel 2. Kriteria

\begin{tabular}{rllc}
\hline $\begin{array}{c}\text { Penghasilan } \\
\text { Bulan (Rp) }\end{array}$ & Pekerjaan & Jenis Rumah & $\begin{array}{c}\text { Tanggungan } \\
\text { (orang) }\end{array}$ \\
\hline 1.500 .000 & Tani & Permanen & 1 \\
1.000 .000 & Wirasuata & Permanen & 3 \\
500.000 & Buruh & Kayu & 5 \\
2.000 .000 & Wirasuata & Semi Permanen & 2 \\
1.200 .000 & Tani & Permanen & 4 \\
800.000 & Buruh & Kayu & 1 \\
1.700 .000 & Wirasuata & Semi Permanen & 2 \\
1.300 .000 & Tani & Kayu & 4 \\
900.000 & Buruh & kayu & 3 \\
\hline
\end{tabular}

Tabel 3. Kriteria Penghasilan dan Bobotnya

\begin{tabular}{lc}
\hline Penghasilan / Bulan (Rp) & Bobot \\
\hline $1.500 .000 \mathrm{~s} / \mathrm{d} 4.000 .000$ & 1 \\
$1.000 .000 \mathrm{~s} / \mathrm{d} 1.500 .000$ & 2 \\
$500.000 \mathrm{~s} / \mathrm{d} 1.000 .000$ & 3 \\
Kurang Dari 500.000 & 4 \\
\hline
\end{tabular}

Tabel 4. Kriteria Pekerjaan dan Bobotnya

\begin{tabular}{cc}
\hline Pekerjaan & Bobot \\
\hline Wiraswasta & 1 \\
Tani & 2 \\
Buruh & 3 \\
\hline
\end{tabular}

Tabel 5. Kriteria Jenis Rumah dan Bobotnya

\begin{tabular}{cc}
\hline Jenis Rumah & Bobot \\
\hline Permanen & 1 \\
Semi Permanen & 2 \\
Kayu & 3 \\
\hline
\end{tabular}

Tabel 6. Kriteria Jumlah Tanggungan dan Bobotnya

\begin{tabular}{cc}
\hline Jumlah Tanggungan & Bobot \\
\hline Tidak Memiliki Anak & 1 \\
1 s/d 3Anak & 2 \\
4 s/d 5Anak & 3 \\
Lebih dari 5 Anak & 4 \\
\hline
\end{tabular}

\subsection{Memberikan Nilai Bobot}

Pada proses pembuatan sistem pendukung keputusan, memutuskan Penerima Pertolongan dari Desa, diperlukan pembobotan pada tiap alternatif serta kriteria yang sudah ditetapkan dan disajikan pada Tabel 7.

Tabel 7. Memberikan Nilai Bobot pada kriteria

\begin{tabular}{llll}
\hline Penghasilan & $/$ & Jenis & Jumlah \\
Bulan & Pekerjaan & Rumah & Tanggungan \\
\hline 1 & 2 & 1 & 2 \\
2 & 1 & 1 & 3 \\
3 & 3 & 3 & 4 \\
1 & 1 & 2 & 2 \\
2 & 2 & 1 & 3 \\
3 & 3 & 3 & 2 \\
1 & 1 & 2 & 2 \\
1 & 2 & 3 & 3 \\
3 & 3 & 3 & 3 \\
\hline
\end{tabular}

\subsection{Memberika Raiting Kecocokan}

Penentuan bobot keriteria untuk penerima bantuan desa, yaitu:

$$
\begin{aligned}
& 1 . \mathrm{C} 1=\mathrm{H} 1=40 \%=0,4 \\
& 2 . \mathrm{C} 2=\mathrm{H} 2=30 \%=0,3 \\
& 3 . \mathrm{C} 3=\mathrm{H} 3=20 \%=0,2 \\
& 4 . \mathrm{C} 4=\mathrm{H} 4=10 \%=0,1
\end{aligned}
$$

\subsection{Membuat Matrik Keputusan}

Berikut adalah contoh data yang ada pada bagian penerima bantuan desa, adapun langkah-langkah penyelesaiannya disajikan pada Tabel 8.

Tabel 8. Data Sampel Sebagai Contoh Perhitungan

\begin{tabular}{llll}
\hline $\begin{array}{l}\text { Penghasilan } \\
\text { Bulan }\end{array}$ & $/$ & Jenis & Jumlah \\
\hline 1 & Pekerjaan & Rumah & Tanggungan \\
2 & 2 & 1 & 2 \\
3 & 1 & 1 & 3 \\
1 & 3 & 3 & 4 \\
2 & 1 & 2 & 2 \\
3 & 2 & 1 & 3 \\
1 & 3 & 3 & 2 \\
1 & 1 & 2 & 2 \\
3 & 2 & 3 & 3 \\
\hline
\end{tabular}

Berdasarkan pada Tabel 8 diatas, dapat dibentuk matrik keputusan $\mathrm{X}$ dengan data berikut :

$$
\times\left\{\begin{array}{llll}
1 & 2 & 1 & 2 \\
2 & 1 & 1 & 3 \\
3 & 3 & 3 & 4 \\
1 & 1 & 2 & 2 \\
2 & 2 & 1 & 3 \\
3 & 3 & 3 & 2 \\
1 & 1 & 2 & 2 \\
1 & 2 & 3 & 3 \\
3 & 3 & 3 & 3
\end{array}\right\}
$$

a. Normalisasi untuk Kriteria C1

$$
t_{x y}=\left\{\frac{x_{x y}}{\max _{x} x_{x y}}\right\}
$$

$$
\begin{aligned}
& \mathrm{T}_{11}=\frac{1}{\operatorname{Max}\{1 ; 2 ; 3 ; 1 ; 2 ; 3 ; 1 ; 1 ; 3\}}=\frac{1}{3}=0,3333 \\
& \mathrm{~T}_{12}=\frac{2}{\operatorname{Max}\{1 ; 2 ; 3 ; 1 ; 2 ; 3 ; 1 ; 1 ; 3\}}=\frac{2}{3}=0,6666 \\
& \mathrm{~T}_{13}=\frac{3}{\operatorname{Max}\{1 ; 2 ; 3 ; 1 ; 2 ; 3 ; 1 ; 1 ; 3\}}=\frac{3}{3}=1 \\
& \mathrm{~T}_{14}=\frac{1}{\operatorname{Max}\{1 ; 2 ; 3 ; 1 ; 2 ; 3 ; 1 ; 1 ; 3\}}=\frac{1}{3}=0.3333 \\
& \mathrm{~T}_{15}=\frac{2}{\operatorname{Max}\{1 ; 2 ; 3 ; 1 ; 2 ; 3 ; 1 ; 1 ; 3\}}=\frac{2}{3}=0.6666 \\
& \mathrm{~T}_{16}=\frac{3}{\operatorname{Max}\{1 ; 2 ; 3 ; 1 ; 2 ; 3 ; 1 ; 1 ; 3\}}=\frac{3}{3}=1 \\
& \mathrm{~T}_{17}=\frac{1}{\operatorname{Max}\{1 ; 2 ; 3 ; 1 ; 2 ; 3 ; 1 ; 1 ; 3\}}=\frac{1}{3}=0.3333 \\
& \mathrm{~T}_{18}=\frac{1}{\operatorname{Max}\{1 ; 2 ; 3 ; 1 ; 2 ; 3 ; 1 ; 1 ; 3\}}=\frac{1}{3}=0.3333 \\
& \mathrm{~T}_{19}=\frac{3}{\operatorname{Max}\{1 ; 2 ; 3 ; 1 ; 2 ; 3 ; 1 ; 1 ; 3\}}=\frac{3}{3}=1
\end{aligned}
$$

b. Normalisasi untuk Kriteria C2

$$
t_{x y}=\left\{\frac{x_{x y}}{\max _{x} x_{x y}}\right\}
$$

$$
\begin{aligned}
& \mathrm{T}_{21}=\frac{2}{\operatorname{Max}\{2 ; 1 ; 3 ; 1 ; 2 ; 3 ; 1 ; 2 ; 3 ;\}}=\frac{2}{3}=0.6666 \\
& \mathrm{~T}_{22}=\frac{1}{\operatorname{Max}\{2 ; 1 ; 3 ; 1 ; 2 ; 3 ; 1 ; 2 ; 3 ;\}}=\frac{1}{3}=0.3333 \\
& \mathrm{~T}_{23}=\frac{3}{\operatorname{Max}\{2 ; 1 ; 3 ; 1 ; 2 ; 3 ; 1 ; 2 ; 3 ;\}}=\frac{3}{3}=1 \\
& \mathrm{~T}_{24}=\frac{1}{\operatorname{Max}\{2 ; 1 ; 3 ; 1 ; 2 ; 3 ; 1 ; 2 ; 3 ;\}}=\frac{1}{3}=0.3333 \\
& \mathrm{~T}_{25}=\frac{2}{\operatorname{Max}\{2 ; 1 ; 3 ; 1 ; 2 ; 3 ; 1 ; 2 ; 3 ;\}}=\frac{2}{3}=0.6666 \\
& \mathrm{~T}_{26}=\frac{3}{\operatorname{Max}\{2 ; 1 ; 3 ; 1 ; 2 ; 3 ; 1 ; 2 ; 3 ;\}}=\frac{3}{3}=1
\end{aligned}
$$




$$
\begin{aligned}
& \mathrm{T}_{27}=\frac{1}{\operatorname{Max}\{2 ; 1 ; 3 ; 1 ; 2 ; 3 ; 1 ; 2 ; 3 ;\}}=\frac{1}{3}=0.3333 \\
& \mathrm{~T}_{28}=\frac{2}{\operatorname{Max}\{2 ; 1 ; 3 ; 1 ; 2 ; 3 ; 1 ; 2 ; 3 ;\}}=\frac{2}{3}=0.6666 \\
& \mathrm{~T}_{29}=\frac{3}{\operatorname{Max}\{2 ; 1 ; 3 ; 1 ; 2 ; 3 ; 1 ; 2 ; 3 ;\}}=\frac{3}{3}=1
\end{aligned}
$$

c. Normalisasi untuk Kriteria C3

$$
t_{x y}=\left\{\frac{x_{x y}}{\max _{x} x_{x y}}\right\}
$$

$\mathrm{T}_{31}=\frac{1}{\operatorname{Max}\{1 ; 1 ; 3 ; 2 ; 1 ; 3 ; 2 ; 3 ; 3\}}=\frac{1}{3}=0.3333$

$\mathrm{T}_{32}=\frac{1}{\operatorname{Max}\{1 ; 1 ; 3 ; 2 ; 1 ; 3 ; 2 ; 3 ; 3\}}=\frac{1}{3}=0.3333$

$\mathrm{T}_{33}=\frac{3}{\operatorname{Max}\{1 ; 1 ; 3 ; 2 ; 1 ; 3 ; 2 ; 3 ; 3\}}=\frac{3}{3}=1$

$\mathrm{T}_{34}=\frac{2}{\operatorname{Max}\{1 ; 1 ; 3 ; 2 ; 1 ; 3 ; 2 ; 3 ; 3\}}=\frac{2}{3}=0.6666$

$\mathrm{T}_{35}=\frac{1}{\operatorname{Max}\{1 ; 1 ; 3 ; 2 ; 1 ; 3 ; 2 ; 3 ; 3\}}=\frac{1}{3}=0.3333$

$\mathrm{T}_{36}=\frac{3}{\operatorname{Max}\{1 ; 1 ; 3 ; 2 ; 1 ; 3 ; 2 ; 3 ; 3\}}=\frac{3}{3}=1$

$\mathrm{T}_{37}=\frac{2}{\operatorname{Max}\{1 ; 1 ; 3 ; 2 ; 1 ; 3 ; 2 ; 3 ; 3\}}=\frac{2}{3}=0.6666$

$\mathrm{T}_{38}=\frac{3}{\operatorname{Max}\{1 ; 1 ; 3 ; 2 ; 1 ; 3 ; 2 ; 3 ; 3\}}=\frac{3}{3}=1$

$\mathrm{T}_{39}=\frac{3}{\operatorname{Max}\{1 ; 1 ; 3 ; 2 ; 1 ; 3 ; 2 ; 3 ; 3\}}=\frac{3}{3}=1$

d. Normalisasi untuk Kriteria C4

$$
t_{x y}=\left\{\frac{x_{x y}}{\max _{x} x_{x y}}\right\}
$$

$\mathrm{T}_{41}=\frac{2}{\operatorname{Max}\{2 ; 3 ; 4 ; 2 ; 3 ; 2 ; 2 ; 3 ; 3\}}=\frac{2}{4}=0.5$

$\mathrm{T}_{42}=\frac{3}{\operatorname{Max}\{2 ; 3 ; 4 ; 2 ; 3 ; 2 ; 2 ; 3 ; 3\}}=\frac{3}{4}=0.75$

$\mathrm{T}_{43}=\frac{4}{\operatorname{Max}\{2 ; 3 ; 4 ; 2 ; 3 ; 2 ; 2 ; 3 ; 3\}}=\frac{4}{4}=1$

$\mathrm{T}_{44}=\frac{2}{\operatorname{Max}\{2 ; 3 ; 4 ; 2 ; 3 ; 2 ; 2 ; 3 ; 3\}}=\frac{2}{4}=0.5$

$\mathrm{T}_{45}=\frac{3}{\operatorname{Max}\{2 ; 3 ; 4 ; 2 ; 3 ; 2 ; 2 ; 3 ; 3\}}=\frac{3}{4}=0.75$

$\mathrm{T}_{46}=\frac{2}{\operatorname{Max}\{2 ; 3 ; 4 ; 2 ; 3 ; 2 ; 2 ; 3 ; 3\}}=\frac{2}{4}=0.5$

$\mathrm{T}_{47}=\frac{2}{\operatorname{Max}\{2 ; 3 ; 4 ; 2 ; 3 ; 2 ; 2 ; 3 ; 3\}}=\frac{2}{4}=0.5$

$\mathrm{T}_{48}=\frac{3}{\operatorname{Max}\{2 ; 3 ; 4 ; 2 ; 3 ; 2 ; 2 ; 3 ; 3\}}=\frac{3}{4}=0.75$

$\mathrm{T}_{49}=\frac{3}{\operatorname{Max}\{2 ; 3 ; 4 ; 2 ; 3 ; 2 ; 2 ; 3 ; 3\}}=\frac{3}{4}=0.75$

3.7 Berdasarkan hasil perhitungan normalisasi matriks $\mathrm{X}$, maka dapat ditentukan matriks ternormaliasai $\mathrm{R}$ sebagai berikut :

$$
R=\left\{\begin{array}{cccc}
0.3333 & 0.6666 & 0.3333 & 0.5 \\
0.6666 & 0.3333 & 0.3333 & 0.75 \\
1 & 1 & 1 & 1 \\
0.3333 & 0.3333 & 0.6666 & 0.5 \\
0.6666 & 0.6666 & 0.3333 & 0.75 \\
1 & 1 & 1 & 0.5 \\
0.3333 & 0.3333 & 0.6666 & 0.5 \\
0.3333 & 0.6666 & 1 & 0.75 \\
1 & 1 & 1 & 0.75
\end{array}\right\}
$$

3.8 Berikutnya tahap terakhir buat memperoleh proses perangkingan ialah dengan metode mengkalikan bobot $(\mathrm{H})$ dengan matrik yang sudah ternormalisasi ( R) dengan menggunakan Rumus (5).

$$
T_{1}=\sum_{j=1}^{n} H_{y} t_{x y}
$$

\section{Diketahui $\mathrm{H}=\left[\begin{array}{llll}0.4 & 0.3 & 0.2 & 0.1\end{array}\right]$}

V1

$$
\begin{aligned}
& =(0.4)(0.3333)+\quad(0.3)(0.6666) \\
& (0.2)(0.3333)+(0.1)(0.5) \\
& =0.1333+0.1999+0.0666+0.05 \\
& =0,4498
\end{aligned}
$$

$\mathrm{V} 2$

$$
\begin{aligned}
& =\quad(0.4)(0.6666)+(0.3)(0.3333)+ \\
& (0.2)(0.3333)+(0.1)(0.75)
\end{aligned}
$$$$
=0.2666+0.0999+0.0666+0.075
$$$$
=0.5081
$$

$=(0.4)(1)+(0.3)(1)+(0.2)(1)+(0.1)(1)$

$=0.4+0.3+0.2+0.1$

$=1$

V4

$$
\begin{aligned}
& =\quad(0.4)(0.3333)+(0.3)(0.3333)+ \\
& (0.2)(0.6666)+(0.1)(0.5) \\
& =0.1333+0.0999+0.1333+0.05 \\
& =0.4165
\end{aligned}
$$

$$
=(0.4)(0.6666)+(0.3)(0.6666)+
$$$$
(0.2)(0.3333)+(0.1)(0.75)
$$$$
=0.2666+0.1999+0.0666+0.075
$$$$
=0,6083
$$

$$
\begin{array}{ll}
\text { V6 } & =(0.4)(1)+(0.3)(1)+(0.2)(1)+(0.1)(0.5) \\
& =0,4+0.3+0.2+0.05 \\
& =0,95 \\
& =(0.4)(0.3333)+(0.3)(0.3333)+ \\
& (0.2)(0.6666)+(0.1)(0.5) \\
& =0.1333+0.0999+0.1333+0.05 \\
& =0,4165 \\
& =(0.4)(0.3333)+(0.3)(0.6666)+(0.2)(1)+ \\
\text { V8 } & (0.1)(0.75) \\
& =0,1333+0.1999+0.2+0.075 \\
& =0,6082 \\
& =(0.4)(1)+(0.3)(1)+(0.2)(1)+(0.1)(0.75) \\
\text { V9 } & 0.4+0.3+0.2+0.075 \\
& =0,975
\end{array}
$$

Ke semua nilai peringkat V1 - V9 dari hasil perkalian dengan normalisasi digabungkan dalam Tabel 9, sehingga diperoleh hasil pembobotan yang disajikan pada Tabel 9.

Tabel 9. Nilai perhitungan preferensi

\begin{tabular}{lllllll}
\hline \multicolumn{1}{c}{ Nama } & $\begin{array}{c}\text { Ko } \\
\text { de }\end{array}$ & $\begin{array}{c}\text { Peng } \\
\text { hasil } \\
\text { an }\end{array}$ & $\begin{array}{c}\text { Pekerja } \\
\text { an }\end{array}$ & $\begin{array}{c}\text { Jenis } \\
\text { Rumah }\end{array}$ & $\begin{array}{c}\text { Jumlah } \\
\text { Tanggu } \\
\text { ngan }\end{array}$ & Hasil \\
\hline Sudarno & K1 & 1 & 2 & 1 & 2 & 0,4498 \\
Widiadi & K2 & 2 & 1 & 1 & 3 & 0.5081 \\
Tukijo & K3 & 3 & 3 & 3 & 4 & 1,0000 \\
Sarkam & K4 & 1 & 1 & 2 & 2 & 0.4165 \\
Yardani & K5 & 2 & 2 & 1 & 3 & 0,6083 \\
Susilawati & K6 & 3 & 3 & 3 & 2 & 0.9500 \\
Suderman & K7 & 1 & 1 & 2 & 2 & 0,4165 \\
Suwarjo & K8 & 1 & 2 & 3 & 3 & 0,6082 \\
Nurman & K9 & 3 & 3 & 3 & 3 & 0,975 \\
\hline
\end{tabular}



Pendukung Keputusan Penerimaan Beras Untuk Keluarga Miskin Menggunakan Metode Simple Additive Weighting di

\subsection{Mendapatkan Hasil Akhir}

Hasil pengelompokan di atas sudah mendapatkan hasil yang sebenarnya untuk ke 9 alternatif penerima bantuan, sehingga perlu dilakukan perengkingan. Hasil perengkingan dari ke 9 warga desa sidoluhur terbaik disajikan pada Tabel 10.

Tabel 10. Hasil Nilai Perengkingan dan Keputusan

\begin{tabular}{llllll}
\hline Kode & $\begin{array}{l}\text { Pengha } \\
\text { silan } \\
\text { Bulan }\end{array}$ & $\begin{array}{l}\text { Pekerja } \\
\text { an }\end{array}$ & $\begin{array}{l}\text { Jenis } \\
\text { Rumah }\end{array}$ & $\begin{array}{l}\text { Jumlah } \\
\text { Tanggu } \\
\text { ngan }\end{array}$ & Hasil \\
\hline K1 & 1 & 2 & 1 & 2 & 0,4498 \\
K2 & 2 & 1 & 1 & 3 & 0.5081 \\
K3 & 3 & 3 & 3 & 4 & 1 \\
K4 & 1 & 1 & 2 & 2 & 0.4165 \\
K5 & 2 & 2 & 1 & 3 & 0,6083 \\
K6 & 3 & 3 & 3 & 2 & 0.95 \\
K7 & 1 & 1 & 2 & 2 & 0,4165 \\
K8 & 1 & 2 & 3 & 3 & 0,6082 \\
K9 & 3 & 3 & 3 & 3 & 0,975 \\
\hline
\end{tabular}

Pada tabel diatas dapat dilihat bahwa Hasil penerima bantuan tidak boleh kurang dari 0.5000 dengan hasil 7 orang penerima bantuan dan 2 orang yang tidak layak menerima bantuan.

\section{Kesimpulan}

Dengan membuat aplikasi sistem pendukung keputusan terhadap jenis dan penerima bantuan desa menggunakan metode SAW dapat memudah kan pekerjaan anggota bansos untuk mengetahui sisapa saja yang berhak sebagai penerima bantuan desa dengan akurat dan tepat.

\section{Daftar Rujukan}

[1] Gunawan, H. (2019). Sistem Pendukung Keputusan Penerima Bantuan Sosial Beras Masyarakat Miskin Menggunakan Metode Simple Additive Weighting (SAW). INTERNAL (Information System Journal), 2(2), 144-152. DOI: https://doi.org/10.32627/internal.v2i2.88 .

[2] Saryoko, A., Muttaqin, S., \& Hidayat, R. (2019). Sistem Penunjang Keputusan Penerima Kartu Indonesia Pintar Menggunakan Metode Simple Additive Weighting (SAW). Jurnal Teknik Komputer, 5(2), 139-146. DOI: https://doi.org/10.31294/jtk.v5i2.4384.

[3] Puspitarini, E. W. (2017). Sistem Pendukung Keputusan dalam Menentukan Penerima BLT dengan Metode Weighted Product Model. SMATIKA JURNAL, 7(02), 31-35.

[4] Parwita, W. G. S., \& Ardini, I. G. A. A. (2019). Sistem Pengelolaan Piutang Pada PT. Human Resources Provider Menggunakan Metode Analisis Aging Schedule dan Simple Additive Weighting. Jurnal Sistem Informasi dan Komputer Terapan Indonesia (JSIKTI), 1(3), 153-164. DOI: https://doi.org/10.33173/jsikti.30 .

[5] Hutahaean, J., \& Badaruddin, M. (2020). Sistem Pendukung Keputusan Pemilihan Sekolah SMK Swasta Penerima Dana Bantuan Menerapkan Metode Simple Additive Weighting (SAW). Jurnal Media Informatika Budidarma, 4(2), 466. DOI: http://dx.doi.org/10.30865/mib.v4i2.2109

[6] Na'am, J. (2017). Sebuah Tinjauan Penggunaan Metode Analytic Hierarchy Process (AHP) dalam Sistem Penunjang Keputusan (SPK) pada Jurnal Berbahasa Indonesia. Mediasisfo, 11(2).
Kantor Kepala Desa Gumpang. Jurnal Teknologi Informasi dan

Komunikasi (TIKomSiN), 6(1). http://dx.doi.org/10.30646/tikomsin.v6i1.351 .

[8] Oktaviani, N., Merlina, N., \& Nurmalasari, N. (2018). Pemilihan Jasa Pengiriman Terbaik Menggunakan Metode Simple Additive Weighting (SAW). Jurnal Sistem dan Teknologi Informasi (JUSTIN), 6(4). DOI: http://dx.doi.org/10.26418/justin.v6i4.29126

[9] Fauzan, R., Indrasary, Y., \& Muthia, N. (2017). Sistem Pendukung Keputusan Penerimaan Beasiswa Bidik Misi di POLIBAN dengan Metode SAW Berbasis Web. Jurnal Online Informatika, 2(2). DOI: https://doi.org/10.15575/join.v2i2.101

[10] Wahyudi, W., Santony, J., \& Nurcahyo, G. W. (2020). Akurasi Keputusan dalam Penentuan Guru Berprestasi dengan Menggunakan Metode Simple Additive Weighting (Studi Kasus Sekolah Menengah Kejuruan Muhammadiyah Batam). Jurnal Sistim Informasi dan Teknologi, 2(1), 9-14. DOI: https://doi.org/10.37034/jsisfotek.v2i1.27 .

[11] Setiadi, I. (2019). Sistem Pendukung Keputusan Pemilihan Mobil Bekas dengan Metode AHP dan SAW pada Nava Sukses Motor. STRING (Satuan Tulisan Riset dan Inovasi Teknologi), 3(3). DOI: http://dx.doi.org/10.30998/string.v3i3.3582 .

[12] Muharsyah, A., Hayati, S. R., Setiawan, M. I., Nurdiyanto, H., \& Yuhandri, Y. (2018). Sistem Pendukung Keputusan Penerimaan Jurnalis Menerapkan Multi Objective Optimization On The Basis of Ratio Analysis (MOORA). Jurikom Jurnal Riset Komputer, 5(1).

[13] Supriadi, A., Nugroho, A., \& Romli, I. (2018). Sistem Pendukung Keputusan Menentukan Siswa Terbaik Menggunakan Metode Simple Additive Weighting (SAW). Jurnal ELTIKOM, 2(1), 26-33. DOI: https://doi.org/10.31961/eltikom.v2i1.39

[14]Resti, N. C. (2017). Penerapan Metode Simple Additive Weighting (SAW) pada Sistem Pendukung Keputusan Pemilihan Lokasi untuk Cabang Baru Toko Pakan UD. Indo Multi Fish. INTENSIF, 1(2), 102. DOI: https://doi.org/10.29407/intensif.v1i2.839 .

[15] Harahap, S. S., \& . Anita. (2019). Sistem Pendukung Keputusan Penyetujuan Kartu Kredit Pada PT. Bank Rakyat Indonesia dengan Menggunakan Metode Simple Additive Weighting (SAW). Jurnal Sistem Informasi dan Ilmu Komputer Prima (JUSIKOM PRIMA), 2(2), 1-7. DOI: https://doi.org/10.34012/jusikom.v2i2.370 .

[16]Riza, R., Hasbi, M., \& Prabowo, I. A. (2018). Sistem Pendukung Keputusan Penanganan Pasien UGD Menggunakan Metode Fuzzy Multiple Attribute Decision Making dengan Simple Additive Weighting Pada Puskesmas Gajahan Surakarta. Jurnal Teknologi Informasi dan Komunikasi (TIKomSiN), 6(1). DOI: http://dx.doi.org/10.30646/tikomsin.v6i1.348

[17] Yulisman, Y., \& Febriani, A. (2020). Sistem Pendukung Keputusan Penentuan Penerima Bantuan Rumah Sehat Layak Huni Menggunakan Metode SAW di Desa Pasir Emas Kecamatan Singingi. Informatika, 12(1). DOI: http://dx.doi.org/10.36723/juri.v12i1.188

[18]Juansen, M., Defit, S., \& Sumijan, S. (2020). Akurasi Penjurusan Bidang Keahlian Teknik Komputer dan Informatika Menggunakan Metode SAW. Jurnal Sistim Informasi dan $\begin{array}{llll}\text { Teknologi, } & \text { 2(3), } & \text { 77-83. }\end{array}$ https://doi.org/10.37034/jsisfotek.v2i3.68 . 
